\title{
NOTCH3 Gene
}

National Cancer Institute

\section{Source}

National Cancer Institute. NOTCH3 Gene. NCI Thesaurus. Code C106436.

This gene plays a role in both intercellular signaling and cell fate determination. 